likewise is controlled by the neurosecretory cells of the brain. The investigation is being continued.

Zoological Laboratory, ELLEN THOMSEN

Royal Veterinary and Agricultural College, Copenhagen.

Dec. 6.

'Scharrer, B., and Scharrer, E., Biol. Bull., 87, 242 (1944).

' Wigglesworth, V. B., Nature, 144, 753 (1939).

Hanström, B., $\boldsymbol{K}$. Fysiog. Salls. Handl. Lund, N.F., 49, Nr. 16 (1938).

-Williams, C. M. (in the press).

- Thomsen, F., Nature, 145, 28 (1940).

- Thomsen, E., Vidensk. Meddel. Dansk naturh. Foren., 106, 320 (1942).

\section{Ribose Nucleic Acid in the Drosophila Egg}

Caspersson and Schultz ${ }^{1,2}$ have claimed that the presence of an extra $Y$-chromosome in the female Drosophila is correlated with an abnormally high concentration of ribose nucleic acid or allied sub. stances containing the pyrimidine ring in the cytoplasm of oocytes. Their graph, based on quantitative determinations of ultra-violet light absorption, indicates that $X X Y$ oocytes contain about 40 per cent more ribose nucleic acid than do $X X$ oocytes. If confirmed, this claim would be evidence for the control exercised by heterochromatin over the synthesis of ribose nucleic acid: and since this substance seems to be closely associated with protein synthesis, the argument might be extended to include a specific connexion between heterochromatin and growth-rate determination.

Brachet $^{3}$ has recently described a simple microchemical method whereby ribose nucleic acid may be estimated quantitatively. The tissue under exam. ination is hydrolysed and distilled in a current of steam. Furfural, the hydrolysis product of ribose sugar which appears in the distillate, is assayed colorimetrically, making use of the coloured compound which it forms with aniline and acetic acid.

Caspersson and Schultz's contention is not directly open to chemical proof since the collection of a homogeneous batch of Drosophila oocytes is impracticable. However, freshly laid eggs can be collected in quantity and these assayed for ribose content.

Such eggs were collected over hourly intervals from the matings $X X \times X Y Y$ and $X X Y \times X Y$. They were dechorionated en masse and fixed in a mixture consisting of equal parts acetone and 10 per cent trichloro-acetic acid. After prolonged extraction in changes of fixative, the eggs were desiccated at $100^{\circ} \mathrm{C}$., extracted with hot ether to remove neutral fat, hydrolysed and distilled. Furfural yields gave the following ribose nucleic acid assays :

\begin{tabular}{|c|c|c|c|}
\hline & $\begin{array}{l}\text { Weight of } \\
\text { ether-extracted } \\
\text { eggs (mgm.) }\end{array}$ & $\begin{array}{l}\text { Yield of } \\
\text { furfural } \\
(\gamma)\end{array}$ & $\begin{array}{l}\text { Estimated } \\
\text { ribose nucleic acid } \\
\text { (mgm. per } \mathrm{gm} . \text { ) }\end{array}$ \\
\hline $\begin{array}{l}\text { Eggg from } \\
X X \text { females }\end{array}$ & $\begin{array}{l}5 \cdot 9 \\
6 \cdot 5 \\
6 \cdot 6 \\
6 \cdot 6 \\
7 \cdot 0\end{array}$ & $\begin{array}{l}11 \cdot 3 \\
13 \cdot 1 \\
13 \cdot 5 \\
11 \cdot 6 \\
13 \cdot 3\end{array}$ & $\begin{array}{r}6.48 \\
6.82 \\
6.94 \\
6.00 \\
\\
6.45 \\
\\
6.54\end{array}$ \\
\hline $\begin{array}{l}\text { Eggs from } \\
\qquad \boldsymbol{X} \boldsymbol{Y} \text { females }\end{array}$ & $\begin{array}{l}4 \cdot 9 \\
6 \cdot 5 \\
6 \cdot 7 \\
7 \cdot 1 \\
8 \cdot 7\end{array}$ & $\begin{array}{r}9 \cdot 6 \\
11 \cdot 7 \\
12 \cdot 7 \\
13 \cdot 1 \\
19 \cdot 0\end{array}$ & $\begin{array}{l}6 \cdot 61 \\
6 \cdot 11 \\
6 \cdot 41 \\
6 \cdot 25 \\
7 \cdot 39 \\
6 \cdot 55\end{array}$ \\
\hline
\end{tabular}

From these figures it is evident that there is no significant difference in the ribose nucleic acid content of newly laid eggs deriving from $X X$ and $X X Y$ parent flies. In keeping with this result it should be further mentioned that in other experiments, to be described in detail elsewhere, no difference either in developmental-rate or in oxygen consumption was found to exist between these two types of eggs.

\section{Institute of Animal Genetics, King's Buildings, Edinburgh 9. Dec. 11.}

1 Caspersson, T., and Schultz, J., Nature, 142, 294 (1938).

${ }^{2}$ Schultz, J., and Caspersson, T., Archiv. Exp. Zellf., 22, 650 (1939).

'Brachet, J., Enzymologia, 10, 87 (1941).

\section{Trypanosoma heptatretæ sp. n., a Blood Parasite of the Hagfish}

HITHERTo the occurrence of a trypanosome in the blood of the hagfish Heptatretus cirrhatus (Bloch and Schneider, 1801) seems to have escaped notice. The type slide of Trypanosoma heptatretoe was prepared from the peripheral blood of a hagfish found stranded at Island Bay, Wellington. Seventeen (57 per cent) of thirty hagfish so far examined have been infected with this hæmoflagellate. One infection was so heavy that an average of three trypanosomes were present in each field when freshly drawn blood was studied under oil immersion $(1.8 \mathrm{~mm}$.) and a $\times 10$ ocular.

Trypanosoma heptatretoe is of long, slender form, its body tapering to a point posteriorly. Its dimen. sions, from the measurement of one hundred specimens fixed with 4 per cent osmic acid vapour and stained with Giemsa's stain, are as follows :

$\begin{array}{lcr} & \text { Average } & \text { Range } \\ \text { Length of free flagellum } & 21 \mu & 18-24 \mu \\ \text { Length of body } & 61 \mu & 56-65 \mu \\ \text { Total length } & 82 \mu & 75-86 \mu \\ \text { Width of body at nucleus } & 3 \cdot 0 \mu & 2 \cdot 8-3 \cdot 1 \mu \\ \text { Width of undulating membrane } & 2 \cdot 5 \mu & 2 \cdot 3-2 \cdot 7 \mu \\ \text { Diameter of karyosome } & 2 \cdot 3 \mu & 2 \cdot 0-2 \cdot 5 \mu\end{array}$

The length of the free flagellum averages 37 per cent (30-43 per cent) of that of the body. The nucleus lies 40 per cent (35-44 per cent) of the bodylength from the root of the free flagellum, and occupies almost the entire width of the body. A parabasal body is situated 5 per cent (4-7 per cent) of the body-length from the posterior end, and the axoneme terminates at a blepharoplast immediately anterior to this structure.

$T$. heptatretce also occurs in a very much scarcer stout form which has the free flagellum much shorter than that of the common form described above. The body is correspondingly lengthened and very markedly widened, but the overall length is not increased. In this stout form the nucleus is appreciably larger than in the slender form, and occupies a more central position. Measurements of the only three specimens encountered to date give the average length of the free flagellum as $12 \mu$ and that of the body as $70 \mu$. The width of the body at the nucleus averages $6 \cdot 3 \mu$, while the diameter of the nucleus itself is $4.6 \mu$ and that of the karyosome $3 \cdot 3 \mu$.

In both slender and stout forms the nucleus is of circular shape, and contains a large central karyosome. The space between karyosome and nuclear membrane appears as a clear, vacuolated ring in living specimens. With Giemsa's stain, used either after dry fixation with absolute alcohol or wet fixa. tion with 4 per cent osmic acid vapour, the karyosome takes on a purplish-pink colour. The vacuolated 